\title{
Anti-hyperlipidemia and Anti-arteriosclerosis Effects of Laminaria japonica in Sprague-Dawley Rats
}

\author{
Seung-Joo Lee ${ }^{1}$, Chong-Wook Kim ${ }^{2}$, Hyuk-Jai Jang ${ }^{2}$, Soon-Yeong Cho ${ }^{1 *}$ and Jong-Won Choi ${ }^{3}$ \\ ${ }^{1}$ Dept. of Food Processing and Distribution, Gangneung-Wonju National University, Gangneung 210-702, Korea \\ ${ }^{2}$ Gangneung Asan Hospital, University of Ulsan College of Medicine, Gangneung 210-711, Korea \\ ${ }^{3}$ College of Pharmacy, Kyungsung University, Busan 608-736, Korea
}

\begin{abstract}
The anti-hyperlipidemic effects of dietary supplementation with sea tangle Laminaria japonica were investigated using an animal model in which normal rats were fed either sea tangle, sea tangle ethanol extract (EE-ST) and sea tangle extracted residue (ER-ST). Total lipid and triglyceride levels in the serum were significantly $(P<0.05)$ reduced in rats fed ER-ST at a dose of $200 \mathrm{mg} / \mathrm{kg}$ body weight when compared to hyperlipidemic control rats. Significant decreases in serum total cholesterol and low density lipoproteincholesterol levels also occurred in rats fed ER-ST at $200 \mathrm{mg} / \mathrm{kg}$ body weight. In addition, the atherosclerosis index and superoxide dismutase in blood lipids were significantly $(P<0.05)$ lowered in rats fed ER-ST at $200 \mathrm{mg} / \mathrm{kg}$ body weight as compared to control rats. In conclusion, sea tangle and ER-ST exhibited beneficial anti-hyperlipidemic and anti-arteriosclerosis effects.
\end{abstract}

Key words: Sea tangle, Antihyperlipidemia, Atheroscrelosis

\section{Introduction}

People today consume saturated fat and cholesterol excessively due to a westernized diet, change in lifestyle, and the increased demands on their time that lead them to pursue convenient eating options that are often less healthy. Excessive saturated fat and cholesterol intake leads to obesity, hyperlipidemia, and cardiovascular diseases such as arteriosclerosis and myocardial infarction, causes regressive processes mediated by lipid peroxides, enhances cancer and aging, and alters or destroys biomembranes (Bidlack and Tappel, 1973; Lee, 1990; Hill et al., 1992). Blood cholesterol concentration is a risk factor for ischemic cerebrovascular diseases and cardioarterial diseases, and free radicals are a known cause of aging and cerebrovascular diseases, cardiovascular diseases, and cancers (Valko et al., 2007). The three major causes of death in 2008 in Korea were malignant neoplasm (cancer), cerebrovascular disease, and heart disease, representing $48.1 \%$ of the total. Statistics show that the mortality rate of heart disease had increased compared to that in 1998, although the mortality rate of cerebrovascular disease decreased (National Statistical Office of Korea, 2010).

Several risk factors of hyperlipidemia have been reported: greater age, sex, obesity, wrong diet, blood pressure, blood sugar, stress, smoking, and the environment. Hyperlipidemia, together with hypertension and smoking, is one of the three major risk factors of cardioarterial disease (Connor et al., 1964).

The main ingredients of sea algae are carbohydrates and minerals. The carbohydrate of sea algae is indigestible dietary fiber, the health benefits of which are recognized. Sea tangle is a perennial brown sea algae that is produced in large quantities; indeed, only the production of seaweed fusiforme, agar, and sea mustard is greater (Ministry of Maritime Affairs and Fisheries, 1999).

The dietary fiber content of sea tangle is $32-75 \%$, which
Open Access http://dx.doi.org/10.5657/FAS.2011.0235

This is an Open Access article distributed under the terms of the Creative Commons Attribution Non-Commercial License (http://creativecommons. org/licenses/by-nc/3.0/) which permits unrestricted non-commercial use, distribution, and reproduction in any medium, provided the original work is properly cited. pISSN: 2234-1749 eISSN: 2234-1757
Received 1 August 2011; Revised 15 September 2011; Accepted 10 November 2011

*Corresponding Author

E-mail: csykang@gwnu.ac.kr 
comprises $51-85 \%$ of water-soluble dietary fiber. Water-soluble and viscous dietary fiber, such as alginic acid and pectin, can reduce low density lipoprotein (LDL)-cholesterol levels, since it tends to absorb or bind to cholesterol. The general mechanism of the cholesterol-reducing effect of water-soluble fiber is hindering the absorption of dietary cholesterol or bile acid (Lahaye, 1991).

The alginic acid-rich sea tangle also contains a high iodine, magnesium, and iron content compared to other sea algae (Nishino et al., 1991). Alginic acid is the main ingredient of the viscous material and has myriad functions, such as reducing blood cholesterol, eliminating heavy metals to the outside of the body, reducing blood pressure, and preventing cancer, in addition to the general functions of dietary fiber, such as improving intestinal function. The alginic acid content of dried sea tangle is $\sim 20 \%$ (Yim, 2007). Recently, the fucoidan contained in brown algae was highlighted as a new physiologically active substance (Choi et al., 1999). Fucoidan, which is a fucose-containing acidic polysaccharide, is known to improve blood flow, reduce clotting, and regulate blood pressure, in addition to its anticancer, anticholesterol, and lipid metabolism functions. Generally, $100 \mathrm{~g}$ of dried sea tangle contains more than $5 \mathrm{~g}$ fucodian. Additionally, sea tangle contains a small quantity of laminine, an amino acid known to reduce blood pressure (Yim, 2007). The healthy benefits of sea tangle are known to originate from fucosterol (Yim, 2007).

In this study, to examine the effect of fucosterol on health indicators, we investigated whether the activity is contained within sea tangle ethanol extract (EE-ST) by administering sea tangle powder, EE-ST, and the extracted residue (ER-ST) to hyperlipidemic rats.

\section{Materials and Methods}

\section{Materials}

Sea tangle (Laminaria japonica) was purchased from Chumunjin Fish Market, Korea, and was collected from Donghae Seaside and dried.

\section{Animal feed}

Ethanol (500 mL; 95\%) was added to $100 \mathrm{~g}$ sea tangle powder in a $1,000-\mathrm{mL}$ Erlenmeyer flask, followed by sonication for $30 \mathrm{~min}$ at $30^{\circ} \mathrm{C}$ (Power Sonic 520; Hwashin Technology, Seoul, Korea). After filtering (Whatman No. 2; Whatman, Maidstone, Kent, UK), extracts were concentrated, frozen, dried in a rotavator (Rotavator R-200; Buchi, Flawil, Switzerland), and stored at $-40^{\circ} \mathrm{C}$. Samples used were sea tangle powder, EE-ST and sea tangle ER-ST.

\section{Raising of experimental animals}

Male Sprague-Dawley $(140 \pm 10 \mathrm{~g})$ rats were provided by Hyochang Science (Daegu, Korea). They were divided into six groups, five rats per group. After a 1-week adaptation period, healthy rats were used. They were provided with a basal diet, a hyperlipidemic diet, or a diet containing sea tangle. Water was provided freely, but diets were measured in the raising term. They were housed at a relative humidity of $50 \pm 10 \%$ and temperature of $22 \pm 3^{\circ} \mathrm{C}$ with a 12-h (07:00-19:00) light/ dark cycle throughout the experiment (Tecniplast, Buguggiati, Italy). Each rat received $200 \mathrm{mg} / \mathrm{kg}$ of sea tangle samples daily for 6 weeks coercively by oral administration. Twenty-four hours before the experiment, only water was offered to the animals. Due to the daily variations in enzyme activity, animals were killed at a fixed time (10:00-12:00).

\section{High-fat diet-induced hyperlipidemia}

Preliminary blood lipid measurements indicated that hyperlipidemia was induced in rats treated with a high-fat diet for 6 weeks. A normal diet was given to rats in the untreated control group, while a high-fat diet was also given to the control and treated groups. Diet compositions are shown in Table 1. The rats were fasted for $8 \mathrm{~h}$ after the final treatment and euthanized with $\mathrm{CO}_{2}$; blood was collected from abdominal aortas. Blood samples were collected from the heart with non-heparinized syringes and incubation on ice for $30 \mathrm{~min}$. Serum was separated by centrifugation at $1400 \mathrm{~g}$ for $10 \mathrm{~min}$ at $4^{\circ} \mathrm{C}$. After microcentrifugation, sera were preserved at $-70^{\circ} \mathrm{C}$.

Table 1. Composition of basal and hyperlipidemic diet ( $\mathrm{g} / \mathrm{kg}$ diet)

\begin{tabular}{|c|c|c|}
\hline Ingredient & Basal diet & Hyperlipidemic diet \\
\hline Casein & 200 & 200 \\
\hline DL-Methionine & 3 & 3 \\
\hline Corn starch & 150 & 150 \\
\hline Sucrose & 500 & 345 \\
\hline Fiber $^{*}$ & 50 & 50 \\
\hline Corn oil & 50 & - \\
\hline AIN-mineral mixture $^{\dagger}$ & 35 & 35 \\
\hline AIN-vitamin mixture & 10 & 10 \\
\hline Choline bitartate & 2 & 2 \\
\hline Beef tallow & - & 205 \\
\hline
\end{tabular}

"Cellulose : Sigma Co. LTD., USA, ${ }^{\dagger}$ Mineral mixture based on the pattern of Rogers and Haper(1965) contain the following ( $\mathrm{g} / \mathrm{kg}$ diet): calcium phosphate dibasic 500.0 , sodium chloride 74.0 , potassium citrate monohydrate 220.0 , potassium sulfate 52.0 , magnesium oxide 24.0 , magnesium carbonate 3.5 , ferric citrate 6.0 , zinc carbonate 1.6 , cupuric carbonate 0.3 , potassium iodate 0.01 , chromium potassium sulfate 0.55 , sucrose, finely powered make $1,000,{ }^{\prime}$ Vitamin mixture(g/kg diet): thiamine $\mathrm{HCl} 0.6$, biotin 0.02 , riboflavin 0.6 , cyanocobalamine 0.001 , pyridoxine $\mathrm{HCl} 0.7$, retinyl acetate 0.8 , nicotinic acid 3.0, DL-tocopherol 3.8, Ca-pantothenate 1.6, 7-dehydrocholesterol 0.0025 , folic acid 0.2 , methionine 0.005 , sucrose, finely powered make 1,000 . 


\section{Weight and fatty tissue weight}

Weight was measured once per week and abdominal fat pad weight was calculated by taking the retroperitoneal and epididymal fat.

\section{Hepatic lipids}

Hepatic lipids were extracted using the procedure developed by Folch et al. (1957), and the hepatic cholesterol and triglyceride concentrations were analyzed with the same enzymatic kit as used for plasma analysis.

\section{Blood lipid content}

Frings and Dunn (1970) sulfo-phospho-vanillin reaction principles were used to determine the blood lipid content. After heating with sulfuric acid together vanillin phosphoric acid, the optical density at $540 \mathrm{~nm}$ was measured, and the lipid level was determined from a standard curve and expressed as $\mathrm{mg} / \mathrm{dL}$.

\section{Total cholesterol levels}

Total serum cholesterol levels were measured using an AM 202-K assay kit (Asan Pharmaceutical Co., Seoul, Korea) prepared by Richmond (1976) according to the manufacturer's instructions. Three milliliters of solution (cholesterol esterase $20.5 \mathrm{U} / \mathrm{L}$, cholesterol oxidase $10.7 \mathrm{U} / \mathrm{L}$, sodium hydroxide $1.81 \mathrm{~g} / \mathrm{L}$, potassium phosphate monobasic $13.6 \mathrm{~g} / \mathrm{L}$, phenol $1.88 \mathrm{~g} / \mathrm{L}$ ) was mixed with $20 \mu \mathrm{L}$ serum and incubated at $37^{\circ} \mathrm{C}$ for $5 \mathrm{~min}$. For the determination of total cholesterol levels, the absorbance at $500 \mathrm{~nm}$ was measured and levels were calculated using a standard curve.

\section{Triglyceride levels}

Triglyceride levels were measured using an AM 157S-K assay kit (Asan Pharmaceutical Co.) prepared by McGowan et al. (1983) according to the manufacturer's instructions. Three milliliters of solution [lipoprotein lipase 10,800 U, glycerol kinase $5.4 \mathrm{U}$, peroxidase $135,000 \mathrm{U}, \mathrm{L}-\alpha$-glycero phosphooxidase $160 \mathrm{U}, N, N$-bis(2-hydroxyethyl)-2-aminomethane sulfonic acid $0.427 \mathrm{~g} / \mathrm{dL}$ ] was mixed with $20 \mu \mathrm{L}$ serum and incubated at $37^{\circ} \mathrm{C}$ for $10 \mathrm{~min}$. For the determination of serum triglyceride levels, the absorbance at $550 \mathrm{~nm}$ was measured and the levels were calculated using a standard curve.

\section{Phospholipid levels}

Phospholipid levels were measured using a kit (Iatron Chemical Co., Tokyo, Japan) prepared by Chen and Anderson (1979) according to the manufacturer's instructions.

\section{High- (HDL) and LDL-cholesterol levels}

Serum HDL-cholesterol levels were measured using an AM 203-K assay kit (Asan Pharmaceutical Co.) prepared by Lehtonen et al. (1986) according to the manufacturer's instructions. Twenty microliters of serum was mixed with $200 \mu \mathrm{L}$ of solution (dextran sulfate $0.1 \%$, magnesium chloride $0.1 \mathrm{M}$ ), incubated at room temperature for $10 \mathrm{~min}$, and centrifuged at $2,500 \mathrm{~g}$ for $10 \mathrm{~min}$. Supernatant $(100 \mu \mathrm{L})$ was mixed with 3 $\mathrm{mL}$ solution [lipoprotein lipase $10,800 \mathrm{U}$, glycerol kinase 5.4 $\mathrm{U}$, peroxidase $135,000 \mathrm{U}, \mathrm{L}-\alpha$-glycero phosphooxidase $160 \mathrm{U}$, $N, N$-bis(2-hydroxyethyl)-2-aminomethane sulfonic acid 0.427 $\mathrm{g} / \mathrm{dL}]$ and incubated at $37^{\circ} \mathrm{C}$ for $5 \mathrm{~min}$. For the determination of serum HDL levels, the absorbance at $500 \mathrm{~nm}$ was measured and levels were calculated as $\mathrm{mg} / \mathrm{dL}$ using a standard curve.

\section{LDL levels}

LDL levels were calculated using the Friedwald (1972) equation:

LDL cholesterol $=[$ total cholesterol $-($ HDL-cholesterol + triglyceride/5)]

\section{Lipid peroxide in serum}

The serum lipid peroxide content was measured according to the method of Yagi (1987). After preincubating the serum with $1 / 12 \mathrm{~N} \mathrm{HSO}$ and $10 \%$ phosphotungstic acid for $5 \mathrm{~min}$, it was then centrifuged. The protein pellet obtained was resuspended in $1 / 12 \mathrm{~N} \mathrm{HSO}$ and $10 \%$ phosphotungstic acid. The resultant protein pellet was resuspended in $1 \mathrm{~mL}$ distilled water, $0.67 \%$ thiobarbituric acid, and $50 \%$ acetic acid at $95^{\circ} \mathrm{C}$ for $60 \mathrm{~min}$; $5 \mathrm{~mL}$ of $n-\mathrm{BuOH}$ was added and the whole was allowed to stand at room temperature. This was centrifuged for $10 \mathrm{~min}$ and the absorbance of the red $n$ - $\mathrm{BuOH}$ layer was measured using a spectrophotometer (JP/V-550; Jasco, Tokyo, Japan) (Ex: $515 \mathrm{~nm}$, Em: $553 \mathrm{~nm}$ ). The malondialdehyde (MDA; unit, $\mathrm{nmol} / \mathrm{mL}$ of serum) content was obtained from a standard curve.

\section{Hydroxyl radical levels}

Serum hydroxyl radical levels were measured according to the method of Kobatake et al. (1987). Briefly, 333.3 $\mu \mathrm{L}$ solution comprising $34.8 \mu \mathrm{L}$ serum, $0.54 \mathrm{M} \mathrm{NaCl}, 0.1 \mathrm{M}$ potassium phosphate buffer ( $\mathrm{pH}$ 7.4), $10 \mathrm{nM} \mathrm{NaN}, 7 \mathrm{nM}$ deoxyribose, $5 \mathrm{nM}$ ferrous ammonium sulfate, and distilled water was vortexed and allowed to stand at $37^{\circ} \mathrm{C}$ for $15 \mathrm{~min}$. This mixture $(67 \mu \mathrm{L})$ was added to $75 \mu \mathrm{L}$ of a solution of $8.1 \%$ sodium dodecyl sulfate, $67 \mu \mathrm{L} \mathrm{20 \%}$ acetic acid, and distilled water, and then $222 \mu \mathrm{L} 1.2 \%$ thiobarbituric acid was added. The final solution was boiled for $30 \mathrm{~min}$ and cooled to room temperature before centrifuging at $700 \mathrm{~g}$ for $5 \mathrm{~min}$. The absor- 
Table 2. Effect of the sea tangle on the body weight in rats fed a normal and hyperlipidemic diet for 6 wk

\begin{tabular}{lccccccc}
\hline & \multirow{2}{*}{$\begin{array}{c}\text { Dose } \\
\text { Treatment }\end{array}$} & \multicolumn{5}{c}{ Body weight (g) } \\
\cline { 3 - 8 } & (mg/kg) & $\mathbf{1} \mathbf{~ w k}$ & $\mathbf{2 ~ w k}$ & $\mathbf{3 ~ w k}$ & $\mathbf{4} \mathbf{~ w k}$ & $\mathbf{5} \mathbf{~ w k}$ \\
\hline Normal & & $69.7 \pm 8.3^{\mathrm{a}}$ & $117.9 \pm 10.6^{\mathrm{a}}$ & $138.5 \pm 19.4^{\mathrm{a}}$ & $181.7 \pm 29.6^{\mathrm{a}}$ & $211.7 \pm 27.2^{\mathrm{a}}$ & $220.8 \pm 28.6^{\mathrm{a}}$ \\
Control & & $88.5 \pm 9.5^{\mathrm{b}}$ & $161.3 \pm 21.3^{\mathrm{b}}$ & $221.7 \pm 30.5^{\mathrm{b}}$ & $251.2 \pm 21.1^{\mathrm{b}}$ & $306.8 \pm 20.5^{\mathrm{c}}$ & $331.7 \pm 31.7^{\mathrm{c}}$ \\
Sea tangle powder & 200 & $85.6 \pm 7.5^{\mathrm{b}}$ & $159.9 \pm 17.3^{\mathrm{b}}$ & $201.4 \pm 18.7^{\mathrm{b}}$ & $235.5 \pm 13.5^{\mathrm{b}}$ & $271.4 \pm 18.3^{\mathrm{bc}}$ & $285.6 \pm 14.9^{\mathrm{b}}$ \\
EE-ST & 200 & $86.8 \pm 8.6^{\mathrm{b}}$ & $163.3 \pm 19.8^{\mathrm{b}}$ & $227.6 \pm 16.2^{\mathrm{b}}$ & $241.1 \pm 19.2^{\mathrm{b}}$ & $287.2 \pm 17.2^{\mathrm{bc}}$ & $288.7 \pm 18.3^{\mathrm{b}}$ \\
ER-ST & 200 & $86.9 \pm 7.8^{\mathrm{b}}$ & $162.6 \pm 18.6^{\mathrm{b}}$ & $192.3 \pm 17.3^{\mathrm{b}}$ & $227.9 \pm 18.6^{\mathrm{b}}$ & $262.4 \pm 18.6^{\mathrm{b}}$ & $268.9 \pm 15.9^{\mathrm{b}}$ \\
\hline
\end{tabular}

Values are mean \pm SD for six experiments. Values followed by the same letter in each columm are not significantly different $(P<0.05)$.

EE-ST, sea tangle ethanol extract; ER-ST, sea tangle extracted residue.

bance of the supernatant was determined at $532 \mathrm{~nm}$ using a spectrophotometer (JP/V-550; Jasco) and the hydroxyl radical concentration (unit: nmol/mg protein) was calculated from a standard curve.

\section{Superoxide dismutase (SOD) activity}

Serum SOD activity was determined by the method of Oyanagui (1984). Serum was 100 -fold diluted with potassium phosphate buffer ( $\mathrm{pH} 7.8$ ) and $100 \mu \mathrm{L}$ was transferred to a test tube; then $200 \mu \mathrm{L}$ solution A (3 nM hydroxylamine/3 nM hypoxanthine), $200 \mu \mathrm{L}$ solution $\mathrm{B}(7.5 \mathrm{mU} / \mathrm{mL}$ xanthine oxidase with $0.1 \mathrm{mM}$ EDTA-2Na), and $500 \mu \mathrm{L}$ distilled water were added, followed by vortexing. Mixtures were then allowed to stand in $37^{\circ} \mathrm{C}$ water for $40 \mathrm{~min}$. Solution C (2 mL; $300 \mathrm{mg}$ sulfanilic acid/5.0 mg $N$-1-naphtyl-ethylenediamine in 500 $\mathrm{mL} 16.7 \%$ acetic acid) was then added and the mix allowed to stand at room temperature for $20 \mathrm{~min}$. The absorbance was measured at $550 \mathrm{~nm}$ and the SOD activity in serum was calculated from a standard curve.

\section{Protein content and statistical analysis}

The protein content of samples was determined by the method of Lowry et al. (1951). Data were used to calculate the mean and standard deviation. Significant differences were determined by Duncan's multiple range test. A value of $P<$ 0.05 was judged to be statistically significant.

\section{Results and Discussion}

\section{Antiobesity effect}

Table 2 shows the weight change of diet-induced hyperlipidemic Sprague-Dawley rats after the addition of sea tangle to the diet. In weeks 1 and 2, the weight of rats receiving EEST decreased. In the sixth week, the weight declined in rats fed sea tangle powder, EE-ST, and ER-ST as compared to the controls. In particular, the rate of weight decrease was greatest in the group receiving ER-ST. Choi et al. (1999) reported that the sea tangle-mediated weight reduction indicated an antiobesity function (Kang, 2008). Thus, ER-ST may suppress body weight to a greater degree than sea tangle powder and so may be a useful antiobesity and weight-reducing agent.

\section{Fatty tissue weight fluctuations}

Table 3 shows of the effect of a diet of sea tangle on diet-induced hyperlipidemic Sprague-Dawley rats. We orally added each type of sea tangle to the diet for 4 weeks and determined the fat contents. The retroperitoneal lipid quantities after the addition of sea tangle powder, EE-ST, or ER-ST were $12.0 \pm$ $1.3 \mathrm{mg} / \mathrm{g}, 13.8 \pm 1.5 \mathrm{mg} / \mathrm{g}$, and $9.4 \pm 1.5 \mathrm{mg} / \mathrm{g}$, respectively, compared to the control group $(14.9 \pm 2.1 \mathrm{mg} / \mathrm{g})$. In contrast, the epididymal lipid quantity after the addition of ER-ST was $9.4 \pm 0.9 \mathrm{mg} / \mathrm{g}$, a $24 \%$ decrease from the $12.4 \pm 1.4 \mathrm{mg} / \mathrm{g}$ of the control group. These results indicate ER-ST had the greatest effect on local fat stores, likely due to its fiber content.

\section{Serum lipid composition}

Table 4 shows the concentration of serum lipid components after adding sea tangle to hyperlipidemic Sprague-Dawley rats. The phospholipids levels in rats fed ER-ST were $130.5 \pm$ $10.3 \mathrm{mg} / \mathrm{dL}$, a $12.2 \%$ decrease compared to the $148.7 \pm 10.2$ $\mathrm{mg} / \mathrm{dL}$ of the control group. Also, the rate of serum triglycer-

Table 3. Abdominal fat pad weight in the normal and fat diet-induced rats fed the sea tangle for $4 \mathrm{wk}$

\begin{tabular}{lccc}
\hline \multirow{2}{*}{ Treatment } & \multirow{2}{*}{$\begin{array}{c}\text { Dose } \\
\text { (mg/kg) }\end{array}$} & \multicolumn{2}{c}{$\mathbf{m g} / \mathbf{g}$ Body weight } \\
\cline { 3 - 4 } & & Retroperitoneal & Epididymal \\
\hline Normal & $6.3 \pm 3.2^{\mathrm{a}}$ & $7.8 \pm 2.0^{\mathrm{a}}$ \\
Control & & $14.9 \pm 2.1^{\mathrm{c}}$ & $12.4 \pm 1.4^{\mathrm{c}}$ \\
Sea tangle powder & 200 & $12.0 \pm 1.3^{\mathrm{bc}}$ & $11.2 \pm 0.8^{\mathrm{bc}}$ \\
EE-ST & 200 & $13.8 \pm 1.5^{\mathrm{c}}$ & $11.8 \pm 0.9^{\mathrm{bc}}$ \\
ER-ST & 200 & $9.4 \pm 1.5^{\mathrm{ab}}$ & $9.4 \pm 0.9^{\mathrm{ab}}$ \\
\hline
\end{tabular}

Values are mean \pm SD for six experiments. Values followed by the same letter in each columm are not significantly different $(P<0.05)$.

EE-ST, sea tangle ethanol extract; ER-ST, sea tangle extracted residue. 
ide levels in rates fed sea tangle and ER-ST were $183.2 \pm 10.2$ $\mathrm{mg} / \mathrm{dL}$ and $158.2 \pm 10.1 \mathrm{mg} / \mathrm{dL}$, respectively, an $8.5 \%$ and $21.0 \%$ decrease from the $200.3 \pm 12.4 \mathrm{mg} / \mathrm{dL}$ of the control group. Vahouny et al. (1980) reported that the combination of fiber with bile salt was the major mediator of reduced lipid absorption. Akiba and Matsumoto (1982) also observed that fiber decreased serum phospholipid levels. Furthermore, Goode et al. (1995) reported that serum lipid content was intimately related with blood pressure, and that a patient with high blood pressure has a higher total serum lipid level. Thus, these data suggest that the addition of sea tangle to the diet resulted in reduced hyperlipidemia.

\section{Serum cholesterol and atherogenic indices}

Table 5 shows the effect of sea tangle samples on serum cholesterol content and atherosclerosis indices in diet-induced hyperlipidemic rats. The serum total cholesterol in rats with diet-induced hyperlipidemia was $91.6 \pm 5.2 \mathrm{mg} / \mathrm{dL}$. However, administration of sea tangle powder and ER-ST lowered this

Table 4. Effect of the sea tangle on the concentration of serum lipids in rats fed a hyperlipidemic diet for $4 \mathrm{wk}$

\begin{tabular}{lccc}
\hline Treatment & $\begin{array}{c}\text { Dose } \\
(\mathbf{m g} / \mathbf{k g})\end{array}$ & $\begin{array}{c}\text { Phospholipid } \\
(\mathbf{m g} / \mathbf{d L})\end{array}$ & $\begin{array}{c}\text { Triglyceride } \\
(\mathbf{m g} / \mathbf{d L})\end{array}$ \\
\hline Normal & & $120.4 \pm 14.6^{\mathrm{a}}$ & $68.7 \pm 7.3^{\mathrm{a}}$ \\
Control & & $148.7 \pm 10.2^{\mathrm{b}}$ & $200.3 \pm 12.4^{\mathrm{c}}$ \\
Sea tangle powder & 200 & $136.9 \pm 10.1^{\mathrm{ab}}$ & $183.2 \pm 10.2^{\mathrm{c}}$ \\
EE-ST & 200 & $141.9 \pm 11.2^{\mathrm{ab}}$ & $187.8 \pm 8.4^{\mathrm{c}}$ \\
ER-ST & 200 & $130.5 \pm 10.3^{\mathrm{ab}}$ & $158.2 \pm 10.1^{\mathrm{b}}$ \\
\hline
\end{tabular}

Values are mean $\pm S D$ for six experiments. Values followed by the same letter in each columm are not significantly different $(P<0.05)$. EE-ST, sea tangle ethanol extract; ER-ST, sea tangle extracted residue.

Table 5. Effect of the sea tangle on serum cholesterol and Al in rats fed a hyperlipidemic diet for $4 \mathrm{wk}$

\begin{tabular}{|c|c|c|c|c|c|}
\hline \multirow{2}{*}{ Treatment } & \multirow{2}{*}{$\begin{array}{c}\text { Dose } \\
(\mathrm{mg} / \mathrm{kg})\end{array}$} & \multicolumn{3}{|c|}{ Cholesterol (mg/dL) } & \multirow{2}{*}{ AI } \\
\hline & & Total & HDL & LDL & \\
\hline Normal & & $56.8 \pm 6.3^{\mathrm{a}}$ & $41.6 \pm 2.4^{c}$ & $2.6 \pm 0.6^{\mathrm{a}}$ & $0.4 \pm 0.1^{\mathrm{a}}$ \\
\hline Control & & $91.6 \pm 5.2^{\mathrm{d}}$ & $31.8 \pm 1.2^{\mathrm{a}}$ & $7.6 \pm 0.9^{b}$ & $1.9 \pm 0.2^{\mathrm{e}}$ \\
\hline $\begin{array}{c}\text { Sea tangle } \\
\text { powder }\end{array}$ & 200 & $81.7 \pm 4.2^{\mathrm{bc}}$ & $35.2 \pm 1.5^{\mathrm{b}}$ & $7.0 \pm 0.5^{b}$ & $1.3 \pm 0.1^{\mathrm{c}}$ \\
\hline EE-ST & 200 & $88.5 \pm 3.2^{\mathrm{cd}}$ & $34.3 \pm 1.5^{\mathrm{ab}}$ & $7.4 \pm 0.6^{\mathrm{b}}$ & $1.6 \pm 0.1^{\mathrm{d}}$ \\
\hline ER-ST & 200 & $74.3 \pm 3.2^{\mathrm{b}}$ & $37.3 \pm 1.2^{\mathrm{b}}$ & $6.6 \pm 0.5^{\mathrm{b}}$ & $1.0 \pm 0.1^{\mathrm{b}}$ \\
\hline
\end{tabular}

Values are mean \pm SD for six experiments. Values followed by the same letter in each columm are not significantly different $(P<0.05)$.

$\mathrm{Al}$ (atheroscrelosis Index) $=($ total cholesterol $-\mathrm{HDL}$ cholesterol) $/ \mathrm{HDL}$ cholesterol.

EE-ST, sea tangle ethanol extract; ER-ST, sea tangle extracted residue. to $81.7 \pm 4.2$ and $74.3 \pm 3.2 \mathrm{mg} / \mathrm{dL}$, respectively, representing $10.8 \%$ and $18.9 \%$ decreases. In contrast, ER-ST administration had the greatest effect on HDL-cholesterol levels, increasing them to $37.3 \pm 1.2 \mathrm{mg} / \mathrm{dL}, 17.3 \%$ higher than the $31.8 \pm 1.2 \mathrm{mg} / \mathrm{dL}$ of the control group. This result is similar to that of another report, in which the sea algae supplementation reduced serum total lipid by $15-20 \%$ in exogenous obesity and arteriosclerosis mice (Nishino et al., 1991). Additionally, the result is consistent with the work of Hsueh and colleagues, who reported that HDL-cholesterol level was increased by oral administration of sea tangle and $200 \mathrm{mg} / \mathrm{kg}$ of sea tangle alginic acid extract (Hsueh and Anderson, 1992). LDL-cholesterol levels were $7.6 \pm 0.9 \mathrm{mg} / \mathrm{dL}$ in diet-induced hyperlipidemic rats, but after administering sea tangle powder, EE-ST, and ER-ST, this decreased to $7.0 \pm 0.5,7.4 \pm 0.6$, and $6.6 \pm 0.5$ $\mathrm{mg} / \mathrm{dL}$, respectively.

A report has described that fiber decreases lipid absorption in the intestine, increases bile acid excretion, and promotes bile acid synthesis from cholesterol, while decreasing the cholesterol concentration. Also, water-soluble fiber, pectin, gums, mucilages, and sea algae polysaccharide, reportedly decrease the total cholesterol and LDL-cholesterol concentration, while increasing that of HDL-cholesterol (Park et al., 1994; Yang et al., 1996).

Therefore, we demonstrated the effect of sea tangle and ER-ST on total cholesterol. HDL- and LDL-cholesterol levels were also influenced by ER-ST. These data suggest that the addition of sea tangle effectively improves hyperlipidemia because hyperlipidemia originates from an increased triglyceride synthesis in the small intestine and liver, a decreased HDL-cholesterol synthesis, and increased VLDL-cholesterol synthesis and secretion. Furthermore, atherosclerosis indices were $1.9 \pm 0.2 \mathrm{mg} / \mathrm{dL}$ in diet-induced hyperlipidemic rats, but $1.3 \pm 0.1 \mathrm{mg} / \mathrm{dL}$ in rats fed sea tangle powder, $1.6 \pm 0.1 \mathrm{mg} /$ $\mathrm{dL}$ in rats fed ER-ST, and $1.0 \pm 0.1 \mathrm{mg} / \mathrm{dL}$ in rats fed ER-ST. These represent $31.6,15.8$, and $47.4 \%$ decreases respectively, and indicate that sea tangle lowers atherosclerosis indices.

This experiment showed that a decrease in serum total cholesterol, HDL-cholesterol, and LDL-cholesterol atherosclerosis indices was effective for hyperlipidemia.

\section{Lipid and cholesterol content of hepatic tissue}

Table 6 shows the effect of sea tangle powder and extracts on hepatic lipid concentration and cholesterol content in the diet-induced hyperlipidemic rats. Compared to controls, total lipid in diet-induced hyperlipidemic rats fed sea tangle powder and ER-ST were $30.9 \pm 1.3$ and $29.4 \pm 1.2 \mathrm{mg} / \mathrm{g}$, respectively, with $11.5 \%$ and $15.8 \%$ decreases, respectively. Triglyceride level was $23.9 \pm 1.3 \mathrm{mg} / \mathrm{g}$ in rats fed ER-ST, a $9.5 \%$ decrease from that of the control group $(26.4 \pm 2.1 \mathrm{mg} / \mathrm{g})$. These data suggest that the addition of sea tangle to the diet affects the disease state, suggesting its effect on hyperlipidemia. 
Table 6. Effect of the sea tangle on the hepatic lipid concentration of hepatic tissue of rat fed a hyperlipidemic diet for $4 \mathrm{wk}$

\begin{tabular}{lccrc}
\hline Treatment & Dose (mg/kg) & Total lipid & Triglyceride & Cholesterol \\
\hline Normal & & $16.8 \pm 2.0^{\mathrm{a}}$ & $9.4 \pm 1.0^{\mathrm{a}}$ & $2.6 \pm 0.5^{\mathrm{a}}$ \\
Control & & $34.9 \pm 2.2^{\mathrm{d}}$ & $26.4 \pm 2.1^{\mathrm{b}}$ & $6.3 \pm 0.4^{\mathrm{b}}$ \\
Sea tangle & 200 & $30.9 \pm 1.3^{\mathrm{bc}}$ & $24.9 \pm 1.2^{\mathrm{b}}$ & $6.0 \pm 0.3^{\mathrm{b}}$ \\
$\quad$ powder & & & & \\
EE-ST & 200 & $33.8 \pm 1.4^{\mathrm{cd}}$ & $25.8 \pm 1.3^{\mathrm{b}}$ & $6.1 \pm 0.4^{\mathrm{b}}$ \\
ER-ST & 200 & $29.4 \pm 1.2^{\mathrm{b}}$ & $23.9 \pm 1.3^{\mathrm{b}}$ & $5.8 \pm 0.4^{\mathrm{b}}$ \\
\hline
\end{tabular}

Values are presented as $\mathrm{mg} / \mathrm{g}$ of tissue. Values are mean $\pm \mathrm{SD}$ for six experiments. Values followed by the same letter in each columm are not significantly different $(P<0.05)$.

EE-ST, sea tangle ethanol extract; ER-ST, sea tangle extracted residue.

Table 7. Effect of the sea tangle on TBARS concentration of hepatic homogenate of rats fed hyperlipidemic diet for 4 weeks

\begin{tabular}{lcc}
\hline Treatment & Dose (mg/kg) & TBARS (MDA nmol/mg protein) \\
\hline Normal & & $26.9 \pm 3.6^{\mathrm{a}}$ \\
Control & & $52.4 \pm 2.2^{\mathrm{e}}$ \\
Sea tangle powder & 200 & $42.4 \pm 1.9^{\mathrm{c}}$ \\
EE-ST & 200 & $47.9 \pm 2.2^{\mathrm{d}}$ \\
ER-ST & 200 & $36.7 \pm 1.4^{\mathrm{b}}$ \\
\hline
\end{tabular}

Values are mean \pm SD for six experiments. Values followed by the same letter are not significantly different $(P<0.05)$.

TBARS, thiobarbituric acid; MDA, malondialdehyde; EE-ST, sea tangle ethanol extract; ER-ST, sea tangle extracted residue.

Table 8. Effect of the sea tangle on the serum hydroxyl radical and superoxide dismutase activities in rats fed hyperlipidemic diet $4 \mathrm{wk}$

\begin{tabular}{lccc}
\hline Treatment & $\begin{array}{c}\text { Dose } \\
\text { (mg/kg) }\end{array}$ & $\begin{array}{c}\text { Hydroxy radical } \\
\text { (nmol/mg protein) }\end{array}$ & $\begin{array}{c}\text { SOD } \\
\text { (unit/mg protein) }\end{array}$ \\
\hline Normal & & $3.0 \pm 0.4^{\mathrm{a}}$ & $3.5 \pm 0.3^{\mathrm{b}}$ \\
Control & & $5.9 \pm 0.3^{\mathrm{c}}$ & $1.7 \pm 0.2^{\mathrm{a}}$ \\
Sea tangle owder & 200 & $5.2 \pm 0.3^{\mathrm{b}}$ & $1.8 \pm 0.2^{\mathrm{a}}$ \\
EE-ST & 200 & $5.4 \pm 0.3^{\mathrm{bc}}$ & $1.7 \pm 0.1^{\mathrm{a}}$ \\
ER-ST & 200 & $4.9 \pm 0.2^{\mathrm{b}}$ & $1.9 \pm 0.1^{\mathrm{a}}$ \\
\hline
\end{tabular}

Values are mean \pm SD for six experiments. Values followed by the same letter in each columm are not significantly different $(P<0.05)$.

Unit: on unit of superoxide dismutase (SOD) was defined as the which inhibited the reduced of alkaline.

DMSO-mediated adrechrome by $50 \%$ in one $\mathrm{mL}$ of blood.

EE-ST, sea tangle ethanol extract; ER-ST, sea tangle extracted residue.

\section{Thiobarbituric acid (TBARS) levels in hepatic tissue}

Table 7 shows the effect of sea tangle samples on TBARS levels in the hepatic tissue of diet-induced hyperlipidemic rats. These were $52.4 \pm 2.2 \mathrm{nmol} / \mathrm{mg}$ in the control group, 42.4 $\pm 1.9 \mathrm{nmol} / \mathrm{mg}$ in rats fed sea tangle powder, and $36.7 \pm 1.4$ $\mathrm{nmol} / \mathrm{mg}$ in those fed ER-ST, representing $19.1 \%$ and $30.0 \%$ decreases, respectively. Lipid peroxidation, which could be the reason for cancer, atherosclerosis, and aging, is considered a cell damage mechanism (Cho and Bang, 2004).

When glycosuria occurs, it is generally accompanied by elevated oxidative stress, itself a result of increases in the tissue lipid peroxidation index. Also, the organized MDA contents of the kidney and liver increased (Celik et al., 2002). When the reasoning is that lipid content increases are caused by these research results, the lipid peroxidation index increased, similar to other research results (Velthuis-te et al., 1996).

Since lipid peroxides can cause regressive diseases, cancer, aging, and changes in biomembranes (Nishide et al., 1993), the anti-oxidizing effect of ER-ST may prevent such conditions. Tissue MDA content is increased by oxidative stress in the case of diabetes.

\section{Serum hydroxyl radical and SOD activities}

Table 8 shows the effect of sea tangle samples on serum hydroxyl radical and SOD activities in diet-induced hyperlipidemic rats. Hydroxyl radical levels in the control group were $5.9 \pm 0.3 \mathrm{nmol} / \mathrm{mg}$, but the administration of sea tangle powder and ER-ST reduced this to $5.2 \pm 0.3$ and $4.9 \pm 0.2$ $\mathrm{nmol} / \mathrm{mg}$, respectively. SOD enzyme activities compared between the control and sea tangle powder and EE-ST groups were completely different. However, SOD enzyme activities of rats fed ER-ST markedly increased. Blood lipid peroxide and active oxygen exhibit cytotoxicity that causes aging and other pathological phenomena related to aging, but this can be ameliorated by the action of the body's detoxification mechanisms.

Animal experiments did not show a significant difference in SOD enzyme activities after oral administration of sea tangle powder, EE-ST, or ER-ST. However, SOD activity was increased to the greatest degree in rats fed ER-ST and sea tangle powder, in which the polysaccharides remain undamaged, when compared to rats fed EE-ST. These data confirmed that ER-ST had the strongest anti-oxidizing effect.

\section{Acknowledgments}

This research was supported by Technology Development Program for Fisheries(108218-03-3-SB010), Ministry for Food, Agriculture, Forestry and Fisheries, Republic of Korea.

\section{References}

Akiba Y and Matsumoto T. 1982. Effects of dietary fibers on lipid metabolism in liver and adipose tissue in chicks. J Nut 112, 15771585.

Bidlack WR and Tappel AL. 1973. Damage to microsomal membrane by lipid peroxidation. Lipids 8, 177-182.

Celik S, Baydaş G and Yilmaz O. 2002. Influence of vitamin E on the 
levels of fatty acids and MDA in some tissues of diabetic rats. Cell Biochem Funct 20, 67-71.

Chen WJ and Anderson JW. 1979. Effects of guar gum and wheat bran on lipid metabolism in rats. J Nutr 109, 1028-1034.

Cho YJ and Bang MA. 2004. Effects of dietary seaweed on blood glucose, lipid and glutathione enzymes in streptozotocin-induced diabetic rats. J Korean Soc Food Sci Nutr 33, 987-994.

Choi JH, Kim DI, Park SH, Kim DW, Lee JS, Ryu JH and Chung YS. 1999. Effects of sea tangle (Laminaria japonica) and fucoidan components on chronic degenerative diseases. Korean J Life Sci 9, 430-438.

Connor WE, Stone DB and Hodges RE. 1964. The interrelated effects of dietary cholesterol and fat upon human serum lipid levels. J Clin Invest 43, 1691-1696.

Folch J, Lees M and Sloane Stanley GH. 1957. A simple method for the isolation and purification of total lipides from animal tissues. J Biol Chem 226, 497-509.

Friedwald WT, Levy RI and Fredrickson DS. 1972. Estimation of the concentration of low-density lipoprotein cholesterol in plasma, without use of the preparative ultracentrifuge. Clin Chem 18, 499502.

Frings CS and Dunn RT. 1970. The colorimetric method for determination of total serum lipids based on the sulfo-phospho-vanillin reaction. Am J Clin Pathol 53, 89-91.

Goode GK, Miller JP and Heagerty AM. 1995. Hyperlipidemia, hypertension, and coronary heart disease. Lancet 345, 362-364.

Hill JO, Lin D, Yakubu F and Peters JC. 1992. Development of dietary obesity in rats: influence of amount and composition of dietary fat. Int J Obes Relat Metab Disord 16, 321-333.

Hsueh WA and Anderson PW. 1992. Hypertension, the endothelial cell, and the vascular complications of diabetic mellitus. Hypertension $20,253-263$

Kang JY. 2008. Anti-inflammatory activities of Undaria pinnatifida and Laminaria japonica (Phaeophyta). MS thesis, Graduate School of Pukyong National University, Busan, KR.

Kobatake Y, Saito M, Kuroda K, Kobayashi S and Innami S. 1987. Influence of fish consumption on serum lipid and lipid peroxide concentrations in middle aged subjects. J Jpn Soc Nutr Food Sci 40, 103-110.

Lahaye M. 1991. Marine algae as sources of fibres: determination of soluble and insoluble dietary fibre contents in some 'sea vegetables'. J Sci Food Agric 54, 587-594.

Lee HK. 1990. Recent progress in obesity research: diseases associated with obesity. Korean J Nutr 23, 341-346.

Lehtonen A and Luutonen S. 1986. High-density lipoprotein cholesterol levels of very old people in the diagnosis of dementia. Age Ageing
$15,267-270$.

Lowry OH, Rosebrough NJ, Farr AL and Rardall RJ. 1951. Protein measurement with the folin phenol reagent. J Biol Chem 193, 265-275.

McGowan MW, Artiss JD, Stramdbergh DR and Zak B. 1983. A peroxidase-coupled method for the colorimetric determination of serum triglycerides. Clin Chem 29, 538-542.

Ministry of Maritime Affairs and Fisheries. 1999. Statistical Year Book of Maritime Affairs and Fisheries. Ministry of Maritime Affairs and Fisheries, Seoul, KR, pp. 1092-1093.

National Statistical Office of Korea. 2010. Annual Report on the Cause of Death Statistics 2008. Daejeon, KR.

Nishide E, Anzai H and Uchida N. 1993. Effects of alginates on the ingestion and excretion of cholesterol in the rat. J Appl Phycol 5, 207-211.

Nishino T, Aizu Y and Nagumo T. 1991. The relationship between the molecular weight and the anticoagulant and activity of two types of fucan sulfates from the brown seaweed Ecklonia kurome. Agric Biol Chem 55, 791-797.

Oyanagui Y. 1984. Reevaluation of assay methods and establishment of kit for superoxide dismutase activity. Anal Biochem 142, 290-296.

Park SH, Lee YK and Lee HS. 1994. The effect of dietary fiber feeding on gastrointestinal functions and lipid and glucose metabolism in streptozotocin-induced diabetic rats. Korean J Nutr 27, 311-322.

Richmond W. 1976. Use of cholesterol oxidase for assay of total and free cholesterol in serum by continuous-flow analysis. Clin Chem $22,1579-1588$.

Vahouny GV, Roy T, Gallo LL, Story JA, Kritchevsky D and Cassidy M. 1980. Dietary fibers. III. Effects of cholesterol absorption and metabolism in the rat. Am J Chin Nutr 33, 2182-2191.

Valko M, Leibfritz D, Monocol J, Cronin MT, Mazur M and Telser J. 2007. Free radicals and antioxidants in normal physiological functions and human disease. Int J Biochem Cell Biol 39, 44-84.

Velthuis-te Wierik EJ, van den Berg H, Weststrate JA. van het Hof KH and de Graaf C. 1996. Consumption of reduced-fat products: effects on parameters of anti-oxidative capacity. Eur J Clin Nutr 50, 214-219.

Yagi K. 1987. Lipid peroxides and human diseases. Chem Phys Lipids 45, 337-351.

Yang JL, Suh MJ and Song YS. 1996. Effects of dietary fibers on cholesterol metabolism in cholesterol-fed rats. J Korean Soc Food Nutr 25, 392-398.

Yim MJ. 2007. Antiatherosclerosis animal study and the ket funtional compound Identification of the alginate extracted residue of sea tangle. MS thesis, Graduate School of Gangneung National University, Gangneung, KR. 